\title{
Seed dispersal by the sun bear Helarctos malayanus in Central Borneo
}

\author{
KIM McCONKEY* and MAURO GALETTI $\dagger$ \\ * Wildlife Research Group, Department of Anatomy, University of Cambridge, Cambridge \\ CB2 3DY, UK (krm20@hermes.cam.ac.uk) \\ $\dagger$ Plant Phenology and Seed Dispersal Research Group, Departamento de Ecologia, Univer- \\ sidade Estadual Paulista, C.P. 199, 13506-900 Rio Claro, São Paulo, Brasil \\ (mgaletti@life.ibrc.unesp.br) \\ (Accepted 24th October 1998)
}

KEY WORDS: Sun bears, Ursidae, Helarctos malayanus, seed dispersal, Borneo, Kalimantan, Indonesia

Bears (Ursidae) are well known consumers of fruits and play an important role as seed dispersers in temperate forests (Welch et al. 1997, Willson 1993 and references therein). For tropical forest-dwelling bear species, however, very little information is known about frugivory and seed dispersal (Young 1990).

The sun bear Helarctos malayanus is the smallest of the living bears, weighing from 24 to $65 \mathrm{~kg}$ (Ward \& Kynaston 1995) and occurring throughout most of South-east Asia (Payne et al. 1985, Ward \& Kynaston 1995). Their diet is described as bees nests (honey), termites, small animals and fruits (Payne et al. 1985). Ridley (1930) suggested that sun bears can disperse seeds of durians (Durio zibethinus, Bombacaceae), but nothing else had been reported on their role as seed dispersers. Here we report observations on the frugivory and seed dispersal by the sun bear in Central Kalimantan, Indonesia.

The observations were carried out at the Barito Ulu Research Area (hereafter Rekut Camp), a 430-ha forest located in Central Kalimantan, Indonesia, at the confluence of the Rekut and Busang Rivers $\left(113^{\circ} 56^{\prime} \mathrm{E}, 0.6^{\circ} \mathrm{S}\right)$. The vegetation is tropical hill evergreen rain forest with a dominance of Dipterocarpaceae (Whitmore 1984). The soils are acidic and low in nutrients 
(Mirmanto 1996) and the forests are considered to produce less fruit than other research areas in Borneo. Consequently large-bodied frugivores such as the orang-utans are virtually absent (Bodmer et al. 1991).

We located sun bear faeces opportunistically along a $20-\mathrm{km}$ trail system, from October 1996 to September 1997. Sun bear defecations were distinguishable by their size and shape. The only other large animal present at Rekut was the pig, whose faeces occurred as distinct pellets. Every sun bear defecation found was marked in the field and the seeds present identified and counted. The age of the defecation was roughly estimated by the dryness of the faeces, and amount of disturbance to the dung, based on the authors' knowledge of primate defecations. Defecations were rechecked and seeds and seedlings counted at least twice, the last check in September 1997. We also tried to locate the nearest fruiting tree of the same species as the defecated seeds to check for claw marks in the trunk which indicated the bears had climbed the tree to seek the fruits. Thirty-five seeds of Canarium pilosum (Burseraceae) collected from sun bear faeces and another 35 from a fruiting tree were tested for germination in the base camp. Seeds were checked daily for germination.

We found 27 sun bear defecations from September 1996 to May 1997 in the Rekut area. Three species were dispersed by the bears, but each defecation contained a single species. In March the remains of one defecation containing 309 seedlings of Erycibe maingayi (seed size $17 \mathrm{~mm} \times 9 \mathrm{~mm}$ ) (Convolvulaceae) was found. This was roughly $150 \mathrm{~m}$ from a conspecific liana that fruited in January. Seedling survival to September was 21\%. A fresh defecation containing seeds of Ficus consociata (Moraceae) was found $200 \mathrm{~m}$ from a conspecific fruiting tree in August. It was not possible to count these seeds due to their high density, but 54 seeds germinated and later died. The remaining 25 defecations were of Canarium pilosum (seed size $18 \mathrm{~mm} \times 16 \mathrm{~mm}$ ) (Burseraceae).

On 27 April, immediately prior to the peak in the fruiting season (in May), a tree of Canarium pilosum was found that had recently finished fruiting. Under the tree were 21 well-formed defecations containing 1515 seeds of this species, and three distinguishable sun bear nests in the tree's canopy. Estimated age of the defecations ranged from 1-3 d, suggesting one or more sun bears (most likely one judging by the claw marks in the tree) had spent several days consuming the fruits. These defecations were spread between 0 and $12.3 \mathrm{~m}$ from the base of the tree, and seed numbers in the drops ranged from 20 to 230 (mean $74.25 \pm 56.13$ ). Overall survival of these seeds was $16.4 \%$, but varied considerably (from 0 to $53 \%$ ).

It was not possible to distinguish the types of death for the Canarium seeds. At the first count $0.5 \%$ of seeds had been infested by insects, but the final rate may have been much higher. Seedling death was obviously high and may have been enhanced by the severe drought which occurred later in 1997. Deposits with high seedling survival were found in small depressions in the ground which held more moisture than surrounding areas. Logistic regression was used to 
determine whether survival of these seedlings could be explained by the number of seeds in the drop, the distance to tree, or the distance to the nearest defecation. The complete model explained $45 \%$ of the variation (maximum-likelihood test, $\mathrm{df}=3, \mathrm{P}<0.001$ ). Distance to the parent tree had the strongest effect $\left(r^{2}=0.34, P<0.001\right)$, followed by seed number $\left(r^{2}=0.20\right.$, $\mathrm{P}<0.001)$. The distance to the nearest defecation had little explanatory power $\left(\mathrm{r}^{2}=0.12, \mathrm{P}<0.001\right)$.

The remaining four defecations containing Canarium seeds were found scattered along the trail systems in late April and early May, between 150 and $400 \mathrm{~m}$ from this fruiting tree. Two of these were recent, and contained 44 and 61 seeds all of which were later predated. The remaining two drops had begun germinating, one containing 38 seeds and seven seedlings all of which died, and the second with $20 \%$ of the 37 seedlings surviving by September. Overall survival for these scattered defecations was $8.7 \%$ but may have been lower if more seeds were originally present in the older drops. These defecations suffered similar removal rates by post-dispersal agents (at least 76\%) and seedling death $(75 \%)$.

Germination of defecated and undefecated Canarium seeds at the camp was very similar. More defecated seeds germinated (74\%) than the control (63\%) but this difference was not significant (difference in binomial proportions, $\mathrm{z}=$ $\left.1.25, \mathrm{P}=0.10 ; \mathrm{n}_{1}=\mathrm{n}_{2}=35\right)$. Defaecated seeds germinated significantly faster (median $26 \mathrm{~d}$ ) than control (median $30 \mathrm{~d}$ ) (Kolmogorov-Smirnoff test stat, $\mathrm{df}=1, \mathrm{P}<0.01)$, but the difference of $4 \mathrm{~d}$ is probably not important to overall survival.

These results describe the seasonal use of fruit sources by sun bears, and some implications for seed dispersal. Welch et al. (1997) found that while large bears required high amounts of animal protein (mainly salmon), small bears of Ursus arctos could rely for considerable periods on fruits. Other authors have also reported seasonal shifts by bears to eat fruit (Joshi et al. 1997, Peyton 1980). Thus it is not unexpected that sun bears, the smallest living Ursidae, may rely on sugar-rich fruits in some periods of the year. During the fruiting peak in May at least three sun bears were present in the 460-ha study area (K. McConkey, unpubl. data). This may have been a seasonal influx of bears to exploit the abundance of fruit, as during the rest of the study period fewer sightings were made of just one bear. Nevertheless, fruit also formed a part of the sun bear diet outside the fruiting peaks as Ficus were eaten in August and Erycibe maingayi probably in January, both of which were relatively poor fruiting months.

No remains of animal matter were detected in the defecations, although there is evidence in the forest at Rekut that bears consume bee weaves (scars on trees). The lack of animal matter in the defecations containing seeds is probably due to the bears' tendency to remain in the fruiting tree until the total depletion of the crop, rather than evidence for complete reliance on fruit. 
Similar behaviour was observed by S. Harrison (unpubl. data) of sun bears consuming Ficus stupenda at the study site.

Sun bears were not the only frugivores consuming the seed species observed in their defecations. Several hornbill species consumed Canarium pilosum fruits, while Prevost's squirrels and gibbons ate Erycibe maingayi. The Ficus fruits were also eaten by these frugivores as well as numerous small birds. Most of these species, particularly the gibbons and hornbills, are efficient seed dispersers and may provide a better service than sun bears (Whitney et al. 1998).

No conclusions can be drawn about the effectiveness of seed dispersal by sun bears due to extreme variability in our observations and low sample size. While the seed survival of some defecations was nil, in others the rate of survival reached 55\%. The main causes of this variation under the Canarium tree, was distance from the parent tree and seed number. As damage by insects was negligible most seedling death was probably by browsing mammals, seedling competition, and the unusually dry conditions during the last few months of the study period (see Howe 1990). Seed predation probably also occurred. The civet Viverra tangalunga is known to eat Canarium seeds, but prefers seeds from fruits over those defecated by sun bears (K. McConkey, unpubl. data).

Ficus seeds were probably not dispersed successfully as hemi-epiphytic species such as this one require specialized sites in the canopy for establishment (Laman 1995), and the defecation found was in a dry spot on the ground. This does not rule out their possibility as dispersers, however, as there was no evidence that they did not defecate in trees.

There are few studies available comparing seed germination rate between bears and other frugivores. Traveset \& Willson (1997) found no difference in seed germination rates between captive birds and bears (black and brown bears) in Alaska, but they did not study the differences in seedling survival in the wild. The role of sun bears and other carnivores, as seed dispersers in central Borneo has been neglected, while most focus has been given to primates and hornbills (see MacKinnon et al. 1996). Our data indicate that sun bears can be important seed dispersers as well, depending on the species consumed, the number of seeds ingested and the deposition site.

\section{ACKOWLEDGEMENTS}

We are grateful to Rupert Ridgeway and David J. Chivers for encouraging our study in the Project Barito Ulu. To Bpk Nordin, Mulyadi, Surian and Arbadi for unlimited help in the field. We thank M. A. Pizo, P. Morellato, C. Peres, L. Curran and an anonymous referee for critical comments on the manuscript. We also thank LIPI and the Indonesian Department of Forestry for permission to work at Rekut, to the New Zealand Embassy in Jakarta, Cambridge Commonwealth Trust and New Zealand Federation of University Women for financial support to K. McConkey and Royal Geographic Society, British Ornithologists' Union and British Airways Assisting Conservation Fund to M. Galetti. 
This paper is based on material collected whilst the author was a participant in the Royal Society's SE Asia Rainforest Research Programme (Publication N ${ }^{\circ}$ $\mathrm{A} / 226)$.

\section{LITERATURE CITED}

BODMER, R. E., MATHER, R. J. \& CHIVERS, D. J. 1991. Rain forests of central Borneo threatened by modern development. Oryx 25: 21-26.

HOWE, H. F. 1990. Seed dispersal by birds and mammals: implications for seedling demography. Pp. 191-218 in Reproductive ecology of tropical forest plants. Bawa, K. S. \& Hadley, M. (eds). Man and the Biosphere Series. Vol. 7. UNESCO, Paris \& Parthenon Publ. Group, Carnforth, UK.

JOSHI, A. R., GARSHELIS, D. L. \& SMITH, J. L. 1997. Seasonal and habitat-related diets of sloth bears in Nepal. Journal of Mammalogy 78:584-597.

LAMAN, T. G. 1995. Ficus stupenda germination and seedling establishment in a Bornean rain forest canopy. Ecology 76:2617-2626.

MAGKINNON, K., HATTA, G., HALIM, H. \& MANGALIK, A. 1996. The ecology of Kalimantan. The ecology of Indonesia. Vol. 3. Periplus Edition, 802 pp.

MIRMANTO, E. 1996. A lowland rain forest fertilization experiment in Central Kalimantan, Indonesia. MSc. thesis, University of Stirling, UK.

PAINE, J., FRANCIS, C. M. \& PHILLIPS, K. 1985. A field guide to the mammals of Borneo. Sabah Society and WWF Malaysia, $332 \mathrm{pp}$.

PEYTON, B. 1980. Ecology, distribution and food habits of spectacled bears, Tremarctos ornatus, in Peru. Journal of Mammalogy 61:639-652.

RIDLEY, H. N. 1930. The dispersal of plants throughout the world. L. Reeve \& Co, Ltd., Kent. 744 pp.

TRAVESET, A. \& WILLSON, M. F. 1997. Effect of birds and bears on seed germination of fleshy-fruited plants in temperate rainforests of southeast Alaska. Oikos 80: 89-95.

WARD, P. \& KYNASTON, S. 1995. Bears of the world. Blandford, London, $191 \mathrm{pp}$.

WELCH, C. A., KEAY, J., KENDALL, K. C. \& ROBBINS, G. T. 1997. Constraints on frugivory by bears. Ecology 78:1105-1119.

WHITMORE, T. C. 1984. Tropical rain forests of the Far East. (2nd Edition). Clarendon Press, Oxford, $282 \mathrm{pp}$.

WHITNEY, K. D. FOGIEL, M. K., LAMPERTI, A. M., HOLBROOK, K. M., STAUFFER, D. J., HARDESTY, B. D., PARKER, V. T. \& SMITH, T. B. 1998. Seed dispersal by Ceratogymna hornbills in the Dja Reserve, Cameroon. Journal of Tropical Ecology 14: 351-371.

WILLSON, M. F. 1993. Mammals as seed-dispersal mutualists in North America. Oikos 67:159-176.

YOUNG, K. R. 1990. Dispersal of Styrax ovatus seeds by the spectabled bear (Tremarctos ornatus). Vida Silvestre Neotropical 2:68-69. 